\title{
EVALUATION OF DYNAMIC INTERACTION OF SURFACE THERMAL TEMPERATURE CHANGES WITH AGRICULTURAL DEVELOPMENT AOCESSES UBDER CLIMATE CHANGE CONDITIONSOF EGYPT
}

\author{
W. K. El Helew*
}

\section{ABSTRACT}

Climate changes and agricultural development processes have a dynamic interaction effects, however, climate change effect on the agricultural biophysical resources and productivity. On the other hand, the agricultural adaption scales and practices effect on the micro/macro climate parameters. Therefore, monitoring and change detection of climate change parameters may be an effective for enhancing the agriculture processes efficiencies. Hereby, the aim of this study was to determine the potential evapotranspiration as reflected with the thermal surface temperature (LST) under climate change conditions of Egypt. Regarding, LST and T average data indicate a decreasing values within about $\left(-1^{\circ} \mathrm{C}\right.$ and $\left.-1.25^{\circ} \mathrm{C}\right)$ had been observed respectively during the study period (1985 - 2017). A predicted equation for estimating the relationship between LST based on NDVI and microclimate parameters had been observed under climate change conditions of Egypt may be statically as follows:

$$
\begin{aligned}
\mathrm{LST} & =21.185-(11.323 * \mathrm{NDVI})+(0.459 \mathrm{Tmean})+(0.7 * \mathrm{SR})- \\
& (0.078 * \mathrm{RH})-(0.587 * \mathrm{WS})+((0.364 * \mathrm{TDEW})
\end{aligned}
$$

A statistically - significant linear trend between annual LST and T average with $R^{2}$ is $\approx 0.76$ and LST with reference Evapotranspiration ETo with $R^{2}$ is $\approx 0.59$, had been obtained.

Key words: Remote Sensing, Normalized Difference Vegetation Index (NDVI) and Potential Evapotranspiration.

* Assist. Prof., Ag. Eng. Dep., Fac. Ag., Ain Shams U., Cairo, Egypt 


\section{INTRODUCTION}

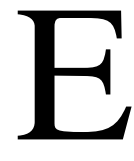

gypt is characterized with limited fresh water resources availability for agricultural development processes and demand. In addition to agricultural sector, it is consumes more than $80 \%$ from the water capita (El-Shirbeny and Abdellatif, 2017). Therefore, it is critical for optimal management of irrigation water in Egypt due to the important conditions of water scarcity. Therefore, in order to overcome this challenge implemented policies of horizontal and vertical expanding in agricultural processes and activities had been considered based on saving irrigation water to cultivate another area(El-Shirbeny et al., 2014).

Good knowledge of climate is important to optimal management and evaluation of many activities including agriculture, natural resources, urbanization, and natural energy (FAO, 2013). On the other hand, a big challenge with creating reliable climate information is related to data availability since meteorological stations may not be present everywhere or in right spatial frequency because of the geographic and economic conditions (Ozelkan et al., 2014). They added that, recently, remote sensing (RS) provides an brilliant opportunity to reach those areas without meteorological stations (Ozelkan et al., 2014). Satellite RS can measure land surface temperature (LST) that is a vital parameter of land surface energy budget (Stroppiana et al., 2014) and climate systems to monitor long-term environmental changes (Guillevic et al., 2012). Due to its relationship with meteorological parameters, LST has been considered as an important input data in different environmental models of land atmosphere energy exchange, numerical weather forecast, global hydrological cycle, climate change, etc.(Duan et al., 2012).

The improvements in remote sensing technology allow obtaining LST from numerous satellites and airborne sensors that support the acquisition of thermal infrared information (kucukali and kusak, 2018; Ranagalage et al., 2017). LST depends mainly on discontinuous vegetation cover that is affected by high temperature or lack of precipitation and significantly increases the vegetation phenology. Usually, high LST values are closely related to lack of vegetation because combined with high air temperature, 
different soil types, under no irrigation conditions, significantly increase the impact on vegetation.

Numerous Studies have been performed on the spatial and temporal patterns of the LST in main land China and other regions of the world, and the analyses of the relationships between regional LST variation and climate change have also been reported for many regions (Bian et al., 2017) Additionally, various studies have been conducted to observe a relationship between land use/cover and the change in land surface temperatures(Li et al., 2013; Hasanlou and Mostofi, 2015; Alhawitti and Mitsova, 2016).

Therefore, the aim of this study was to determine the potential Evapotranspiration as reflected with the thermal surface temperature (LST) under climate change conditions of Egypt.

\section{MATERIALS AND METHODS}

The study area is located at $32^{\circ} 10^{\prime} 58.46^{\prime \prime} \mathrm{E}$ to $32^{\circ} 18^{\prime} 31.784^{\prime \prime} \mathrm{E}$ longitude and $30^{\circ} 26^{\prime} 32.11^{\prime \prime} \mathrm{N}$ to $30^{\circ} 31^{\prime} 8.204^{\prime \prime} \mathrm{N}$ latitude in the Northern East of Egypt, the distance between the study area and the Suez Canal is $2.25 \mathrm{~km}$ at the North and $4 \mathrm{~km}$ at the south and covers an area of approximately $103.19 \mathrm{~km}^{2}$. The mean annual maximum temperature was $29.2^{\circ} \mathrm{C}$, minimum $15.3{ }^{\circ} \mathrm{C}$ and mean $21.7^{\circ} \mathrm{C}$. The mean annual relative humidity is about $48.8 \%$ and mean annual solar radiation is $25.2\left(\mathrm{MJ} / \mathrm{m}^{2} /\right.$ day $)$.

The study area cultivated with the majority forest, which irrigated by drip irrigation system with treated, waste water, however, Sarapium forest had been established since 1996, meanwhile, in 2015 small area had been cultivated crop field under center pivots. Distribution of the area cultivated percentage during the study period (1985 - 2017) as shown in table (1).

\section{2-1 Historical meteorological data:}

Meteorological data were directly recorded from a weather station, which

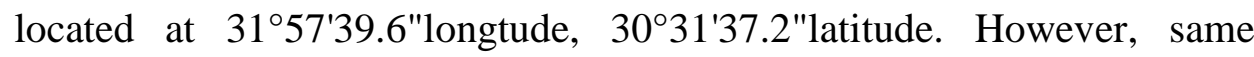
historical data during the same period. The data were used to estimate the ETo based on ETo calculator software. 
Table (1): Distribution of the area cultivated percentage during the study period $(1985$ - 2017).

\begin{tabular}{|c|cccc|}
\hline Year & $\begin{array}{c}\text { Water } \\
\text { area\% }\end{array}$ & $\begin{array}{c}\text { Bare } \\
\text { area\% }\end{array}$ & $\begin{array}{c}\text { Unhealthy } \\
\text { vegetables area\% }\end{array}$ & $\begin{array}{c}\text { Healthy } \\
\text { vegetables area\% }\end{array}$ \\
\hline 1985 & 0.15 & 86.95 & 4.025 & 8.875 \\
1990 & 0.675 & 80.075 & 6.45 & 12.8 \\
1995 & 0.45 & 77.55 & 7.85 & 14.15 \\
2000 & 0.775 & 70.6 & 7.4 & 21.225 \\
2005 & 0.65 & 68.825 & 8.525 & 22 \\
2010 & 0.375 & 63.875 & 9.9 & 25.85 \\
2017 & 0.55 & 40.7 & 20.1 & 38.65 \\
\hline
\end{tabular}

The data were also used to estimate ETo and the following meteorological data were acquired:
a. Maximum air temperature $\left({ }^{\circ} \mathrm{C}\right)$;
b. Minimum air temperature $\left({ }^{\circ} \mathrm{C}\right)$;
c. Relative humidity (\%);
d. Solar radiation $\left(\mathrm{MJ} / \mathrm{m}^{2} /\right.$ day $)$.

\section{2-2 Acquisition of Satellite Images:}

The satellites data has been acquired from U.S. Geological Survey. Images from Landsat-5 Thematic Mapper (TM), Landsat-7 Enhanced Thematic Mapper Plus (ETM+) and Landsat-8 Operational Land Imager (OLI) imagery were used to estimate NDVI and LST. All data sets were registered into Universal Transverse Mercator projection system with WGS 84 datum (UTM-WGS84) and zone 36, north. And they can be identified as WRS -Path 176/Row 39. The details for the satellites data are presented in Table (2).

\section{2-3 Reference Evapotranspiration (ETo):}

The ETo calculator has been used to estimate reference Evapotranspiration. ETo calculator is software developed by Food and Agriculture Organization (FAO). The main function of this calculator is to calculate evapotranspiration (ETo) according to FAO standards. The ETo calculator measures evapotranspiration using meteorological data with the help of FAO Penman-Monteith equation. This method has been selected by FAO as it results in most appropriate value of ETo at certain location (Zahid and Rasul 2011). 
Table (2) Techniques specification of the satellites data used in the study:

\begin{tabular}{|l|llll|}
\hline Sensors & Path/Row & Bands & Resolution (m) & Source \\
\hline Landsat 5 TM & $176 / 39$ & 3,4 & 30 & earthexplorer. \\
& & 6 & $120 \times(30)$ & usgs.gov \\
\cline { 1 - 1 } Landsat 7 ETM+ & $176 / 39$ & 3,4 & 30 & earthexplorer. \\
& & 6.1 & $120 \times(30)$ & usgs.gov \\
\cline { 1 - 1 } Landsat 8 OLI & \multirow{2}{*}{$176 / 39$} & 4,5 & 30 & earthexplorer. \\
& & 10 & $120 \times(30)$ & usgs.gov \\
\hline
\end{tabular}

\section{2-4 Normalized Difference Vegetation Index (NDVI):}

The NDVI values show the amount of green vegetation present in the pixel. NDVI is calculated from the visible and near-infrared light reflected by vegetation (Peltonen-Sainio et al., 2007). NDVI values were derived from TM, ETM+ and OLI images as follows equation:

$$
N D V I=\frac{(N I R-R)}{(N I R+R)}
$$

Where; NIR and R are the spectral reflectance in the TM, ETM+ and OLI red and near-infrared bands.

\section{2-5 Land Surface Temperature (LST):}

For Landsat data, the recorded digital numbers (DN) were converted to radiance units (Rad) using the calibration coefficient specific for each band.

$$
\text { Radiance }=\text { Gain } * \text { DN }+ \text { offset }
$$

Surface emissivity (Eo) was estimated from the Normalized Difference Vegetation Index (NDVI). NDVI using the empirical equation developed from row data on NDVI and thermal emissivity (Valor and Caselles, 1996).

$$
\text { Eo }=0.9932+0.0194 \ln \text { NDVI }
$$

The radiant temperature (To) can be calculated from band 6, 6.1 and 10 (Rad) (Goetz et al., 1995). The thermal Band Calibration Constants was showed in Table (3).

Table (3): OLI, ETM+ and TM Thermal Band Calibration Constants.

\begin{tabular}{|lll|}
\hline & $\mathrm{K} 1\left(\mathrm{Wm}^{-2} \mathrm{sr}^{-1} \mu \mathrm{m}^{-1}\right)$ & $\mathrm{K} 2($ Kelvin $)$ \\
\hline Landsat 8 - OLI & 1321.08 & 774.89 \\
Landsat 7 - ETM+ & 1282.71 & 666.09 \\
Landsat 5 - TM & 1260.56 & 607.76 \\
\hline
\end{tabular}




$$
\begin{array}{lll}
\text { To } & =\mathrm{K} 2 / \operatorname{In}((\mathrm{K} 1 / \operatorname{Rad} 6)+1) & \text { for Landsat } 5 \\
\text { To }=\mathrm{K} 2 / \ln ((\mathrm{K} 1 / \operatorname{Rad} 6.1)+1) & \text { for Landsat } 7 \\
\text { To }=\mathrm{K} 2 / \ln ((\mathrm{K} 1 / \operatorname{Rad} 10)+1) & \text { for Landsat } 8
\end{array}
$$

The resulting temperature (Kelvin) is satellite radiant temperature of the viewed earth atmosphere system, which is correlated, but not the same as, the surface (kinetic) temperature. The atmospheric effects and surface thermal emissivity have to be considered in order to obtain the accurate estimate of surface temperature from satellite thermal data (Norman et al., 1995). The surface temperature is calculated from the top of atmosphere radiant temperature (To) and estimated surface emissivity (Eo) as:

$$
\mathrm{T}=\mathrm{To} / \mathrm{Eo}
$$

To conversion the Temperature unit from Kelvin to the temperature "Celsius": The temperature in Celsius was calculated as the following equation:

$$
\operatorname{LST}\left({ }^{\circ} \mathrm{C}\right)=\mathrm{T}-273.13
$$

By extracting the LST and NDVI values from the satellite images and with data from metrological station were applied to predict LST.

\section{RESULTS AND DISCUSSION}

\section{3-1 Data analysis of Land Surface Temperature (LST): \\ i) Minimum of Land Surface Temperature (LST) images.}

Figure (1) presents LST maps on $\left(11^{\text {th }}\right.$ Feb $1985,24^{\text {th }}$ Dec $1995,17^{\text {th }}$ Jan $2005,15^{\text {th }}$ Dec 2015). These images present an indicator of minimum mean land surface temperature. The ranges of LST were divided to five classes $(\leq 23,>23: 26,>26: 29,>29: 32,>32)$ in Celsius degrees $\left({ }^{\circ} \mathrm{C}\right)$. Meanwhile, data analysis presented in figure (2a) revealed LST map of $11^{\text {th }}$ Feb 1985 the highest-class class 5 represent $82.5 \%$ of the total area at which is corresponding with temperature $\left(>32^{\circ} \mathrm{C}\right)$ while class 1 represent $4.4 \%$ with temperature $(\leq 23)$. In parallel the highest $\mathrm{T}$ mean and Solar Radiation with lowest relative humidity comparison with other dates from the Table (4). LST map on $24^{\text {th }}$ Dec 1995 the percentage of medium class (>26: 29) represent 56.1\%, whereas the highest class declined from 82.5 $\%$ to $0.3 \%$. The decreased in the LST map on $24^{\text {th }}$ Dec 1995 associated with increased in relative humidity and decrease in solar radiation from the tab. 3 comparison of $\left(11^{\text {th }}\right.$ Feb 1985). According to $17^{\text {th }}$ Jan 2005 LST 
map, the percentage of class 4 represents $48.3 \%$. Table (4) shows air temperature recorded the coolest degree. LST map on $15^{\text {th }}$ Dec 2015 the percentage of class 4 (>29: 32) represent 50.7\%, whereas the classes 1,2 and 3 represent $13.2 \%, 13.4$ and 13.8 respectively.

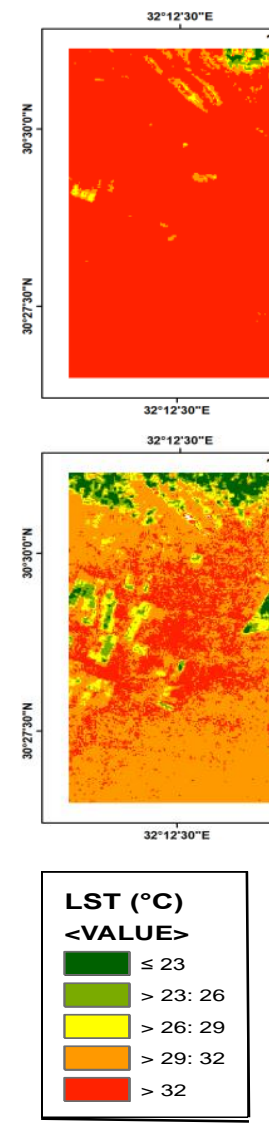

Figure (1): Land surface temperature maps for study area on $\left(11^{\text {th }} \mathrm{Feb}\right.$ $1985,24^{\text {th }}$ Dec $1995,17^{\text {th }}$ Jan 2005 and $15^{\text {th }}$ Dec 2015).

Table (4): Some climate parameters in the study area.

\begin{tabular}{|l|c|c|c|c|}
\hline $\begin{array}{c}\text { Micro } \\
\text { climate parameters }\end{array}$ & $11 / 02 / 1985$ & $24 / 12 / 1995$ & $17 / 01 / 2005$ & $15 / 12 / 2015$ \\
\hline T mean $\left({ }^{\circ} \mathrm{C}\right)$ & 16.3 & 14.7 & 11.2 & 14.9 \\
\hline RH \% & 36.2 & 69.5 & 42.5 & 65.9 \\
\hline Solar Radiation $\left(\mathrm{MJ} / \mathrm{m}^{2} /\right.$ day $)$ & 16.6 & 10.9 & 12.7 & 11.4 \\
\hline
\end{tabular}




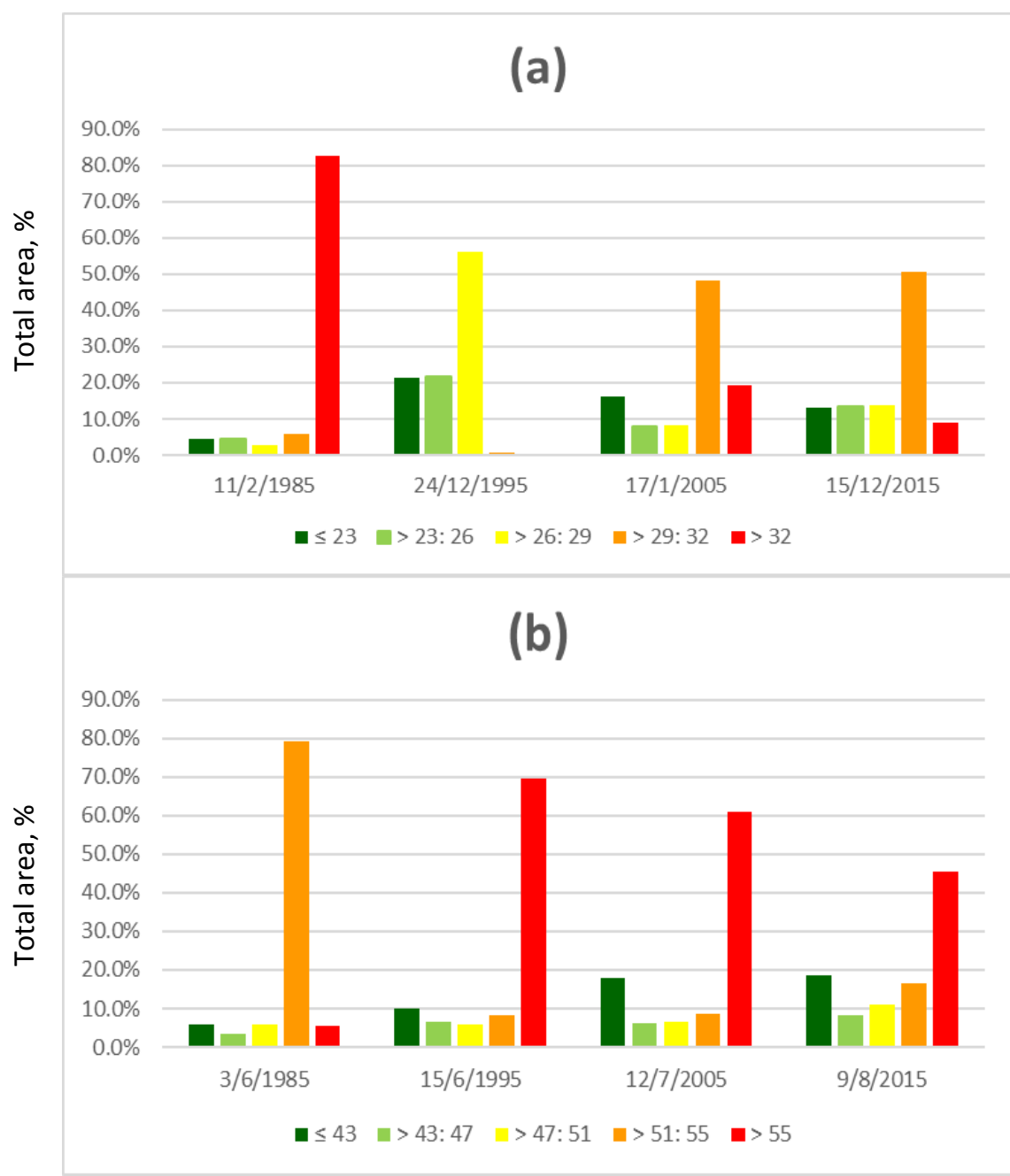

Figure (2): Area statistics of Classification for (a) minimum mean LST $\left(\mathrm{C}^{\circ}\right)$ and (b) maximum mean LST $\left(\mathrm{C}^{\circ}\right)$.

ii) Maximum of Land Surface Temperature (LST):

Figure (3) represents LST maps on $\left(3^{\text {rd }}\right.$ Jun $1985,15^{\text {th }}$ Jun $1995,12^{\text {nd }} \mathrm{Jul}$ $2005,9^{\text {th }}$ Aug 2015). These images present an indicator of maximum mean land surface temperature. The range of LST is divided to five classes $(\leq 43,>43: 47,>47: 51,>51: 55,>55)$ in Celsius degrees $\left({ }^{\circ} \mathrm{C}\right)$. According to figure (2b), and into LST map of $3^{\text {rd }}$ Jun 1985 found that the class 4 represent $79.3 \%$ of the total area at which is corresponding with temperature $\left(>51: 55^{\circ} \mathrm{C}\right)$. LST map on $15^{\text {th }}$ Jun 1995 the percentage of highest class $\left(>55^{\circ} \mathrm{C}\right)$ represent $59.5 \%$, The increasing in the LST map on 
$15^{\text {th }}$ Jun 1995 associated with increased in air temperature and decrease in relative humidity from the table (5). According to $12^{\text {nd }}$ Jul 2005 LST map, the percentage of class 5 represents $61.1 \%$. Also, table (5) shows solar radiation recorded the highest radiation with $28.6\left(\mathrm{MJ} / \mathrm{m}^{2} /\right.$ day), while LST map on $9^{\text {th }}$ Aug 2015 the percentage of highest class $\left(>55^{\circ} \mathrm{C}\right)$ represent $45.4 \%$, whereas the coolest classes represent $18.7 \%$.

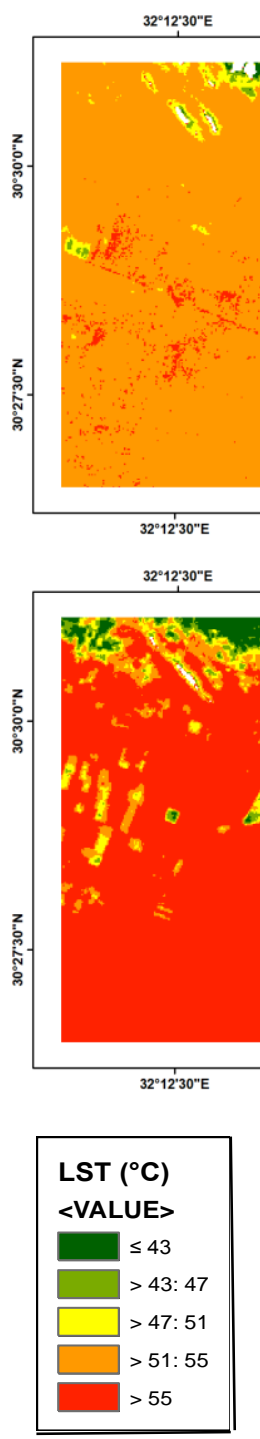

$32^{\circ} 17^{\prime} 30^{\circ E}$

$$
32^{\circ} 15^{\circ} 0 \text { "E }
$$$$
\text { 3- Jun- } 1985
$$
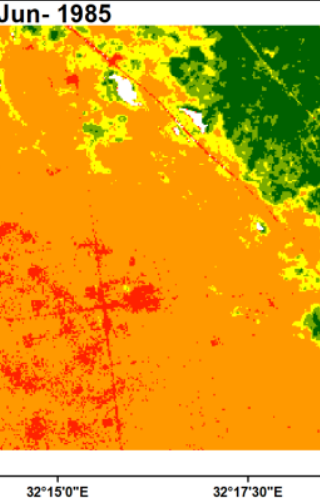

$32^{\circ} 15^{\circ} 0^{\prime \prime} \mathrm{E}$
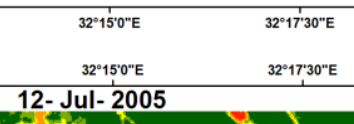

$32^{\circ} 17^{\prime} 30^{\prime \prime E}$

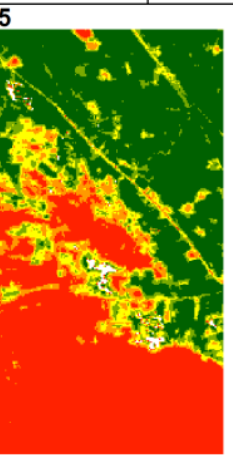

$32^{\circ} 15^{\circ} 0^{\circ \mathrm{E} E}$

$32^{\circ} 17^{\prime} 30^{\prime \prime} \mathrm{E}$
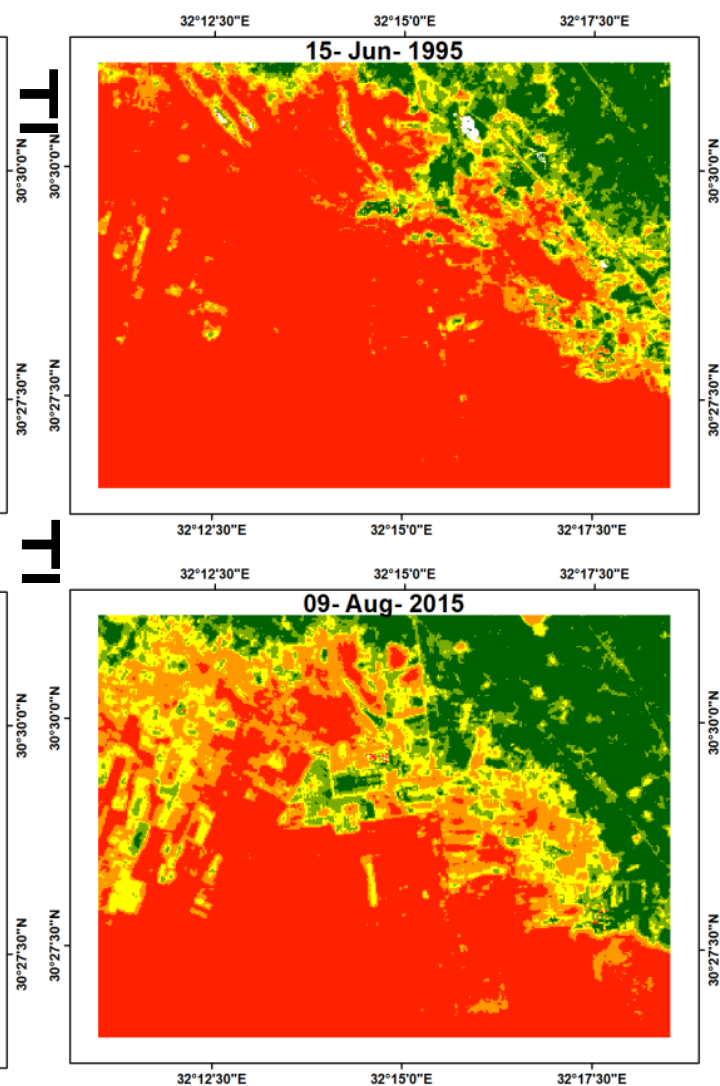

$$
2
$$

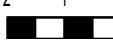

Figure (3): Maps of Land surface temperature for study area on ( $3^{\text {rd }} \mathrm{Jun}$ $1985,15^{\text {th }}$ Jun 1995, $12^{\text {nd }}$ Jul 2005 and $9^{\text {th }}$ Aug 2015). 
Table (5): Some climate parameters in the study area:

\begin{tabular}{|c|c|c|c|c|}
\hline Investigated date & 03/06/1985 & $15 / 06 / 1995$ & $12 / 07 / 2005$ & $09 / 08 / 2015$ \\
\hline $\mathrm{T}$ mean $\left({ }^{\circ} \mathrm{C}\right)$ & 30 & 34.6 & 31.2 & 33.4 \\
\hline RH \% & 28.4 & 27.3 & 36 & 35 \\
\hline Radiation (MJ/m²/day) & 26.7 & 24.6 & 28.6 & 27 \\
\hline
\end{tabular}

3-2 Relationships between Land surface Temperature (LST) and mean air temperature ( $T$ mean):

Data presented in figure (4), indicated that Land Surface Temperature (LST) is an essential parameter of land surface energy budget and climate systems to monitor long-term environmental changes. However, a decrease in LST and $\mathrm{T}$ mean $\left(-1^{\circ} \mathrm{c}\right.$ and $\left.-1.25^{\circ} \mathrm{c}\right)$ respectively during the studied period, but this decreasing is insignificant at $5 \%$.

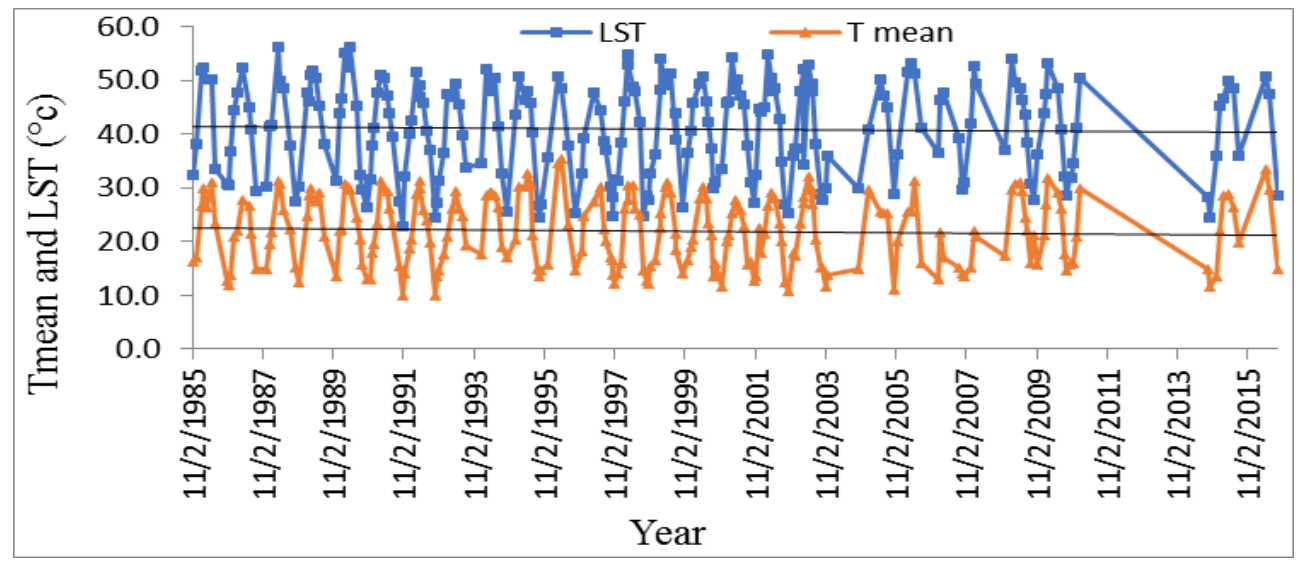

Figure (4): Relationship LST with T mean $\left({ }^{\circ} \mathrm{c}\right)$ during the studied period (1985 - 2015).

\section{3-3 Reference Evapotranspiration (ETo):}

ETo affected directly with climate changes and it depended completely on meteorological data (Temperature, Relative humidity, Wind speed and Solar radiation). When vegetation covers soil $100 \%$, all water losses are 
transpiration. The ETo calculator has been used to estimate Evapotranspiration as showed in Fig. 5. The results showed that high statistically significant change in ETo with increased approximately 1.7 $\mathrm{mm}$ at the period of the study. Maximum, minimum, mean ETo were 11.6, 2.1 and $5.9 \mathrm{~mm} /$ day respectively.

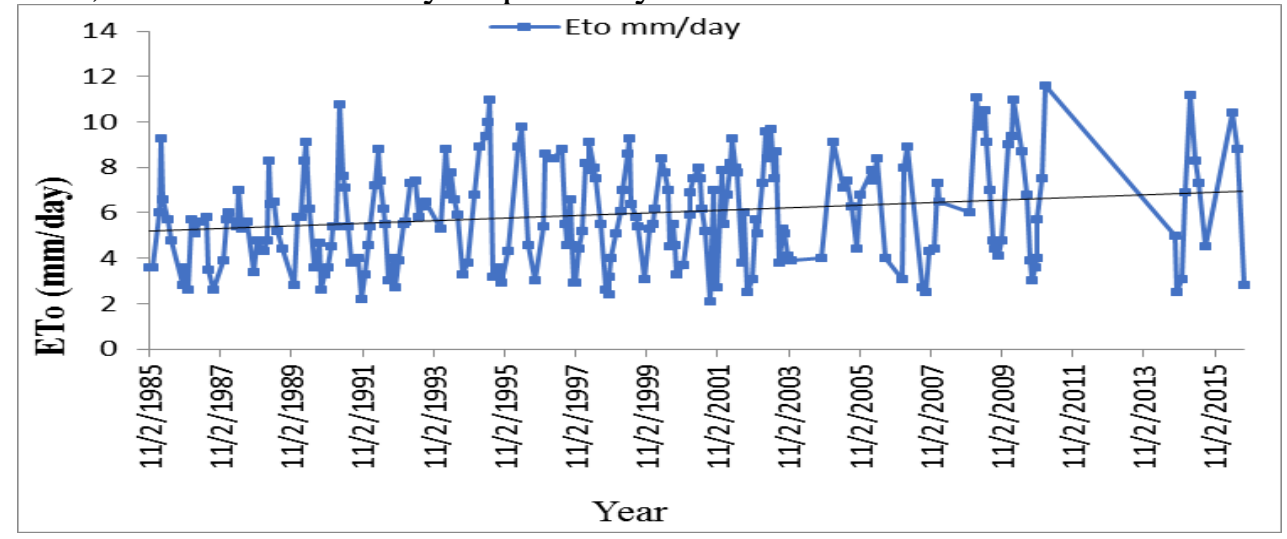

Figure (5): ETo (mm/day) during the period (1985 - 2015) at study area.

\section{3-4 Correlation analysis of LST with $\mathrm{T}$ air and ETo:}

The relation between LST and T air is a positive relationship where the slope is 0.63 , intercept is -3.99 , and $\mathrm{R}^{2}$ is $\approx 0.76$ as shown in figure (6a). The analysis results showed that the correlation between LST with $\mathrm{T}$ air significant at $1 \%$. The relation between LST and ETo is a positive relationship where the slope is 0.19 , intercept is -2.06 , and $\mathrm{R}^{2}$ is $\approx 0.59$ as shown in figure (6b) and it is significant at $1 \%$.

\section{3-5 Observed Land Surface Temperature (LST):}

Results show that the correlation between calculated and observed LST values is $\approx \mathrm{R}^{2}=0.88$ as shown in figure (7). The analysis results showed that the correlation between calculated and predicted ETc is significant and RMSE is $3.03\left({ }^{\circ} \mathrm{c}\right)$.

A predicted equation for estimating the relationship between LST based on NDVI and microclimate parameters had been observed. However, the confidence degree of this equation is $88 \%$ and the RMSE is 3.03 .

$$
\begin{aligned}
& \mathrm{LST}=21.185-(11.323 * \mathrm{NDVI})+(0.459 \mathrm{Tmean})+(0.7 * \mathrm{SR})- \\
& \quad(0.078 * \mathrm{RH})-(0.587 * \mathrm{WS})+((0.364 * \mathrm{TDEW})
\end{aligned}
$$

Where: LST: Land Surface Temperature $\left[{ }^{\circ} \mathrm{c}\right]$; NDVI: Normalized Deference Vegetation Index; $\mathrm{T}$ mean: Mean air temperature [ $\left.{ }^{\circ} \mathrm{c}\right]$; SR: 
Solar radiation $\left[\mathrm{MJ} / \mathrm{m}^{\wedge} 2 /\right.$ day]; RH: Relative humidity [\%]; WS: Wind speed $[\mathrm{m} / \mathrm{s}]$; TDEW: Dew / Frost point temperature $\left[{ }^{\circ} \mathrm{c}\right]$.
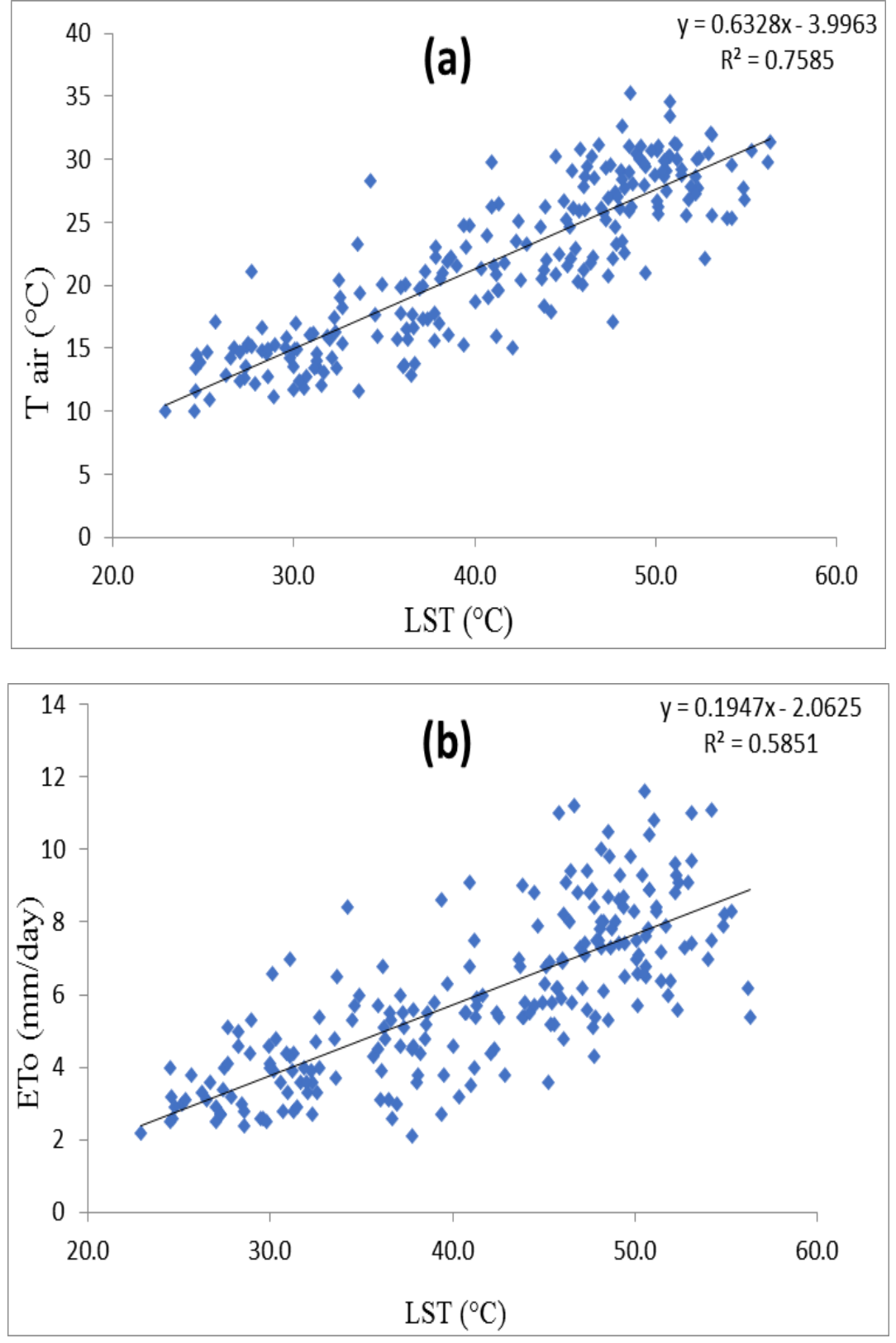

Figure 6: (a) Land surface temperature (in degrees Celsius) and air temperature (in degrees Celsius). (b) Land surface temperature (in degrees Celsius) and Reference Evapotranspiration ( $\mathrm{mm} /$ day). 


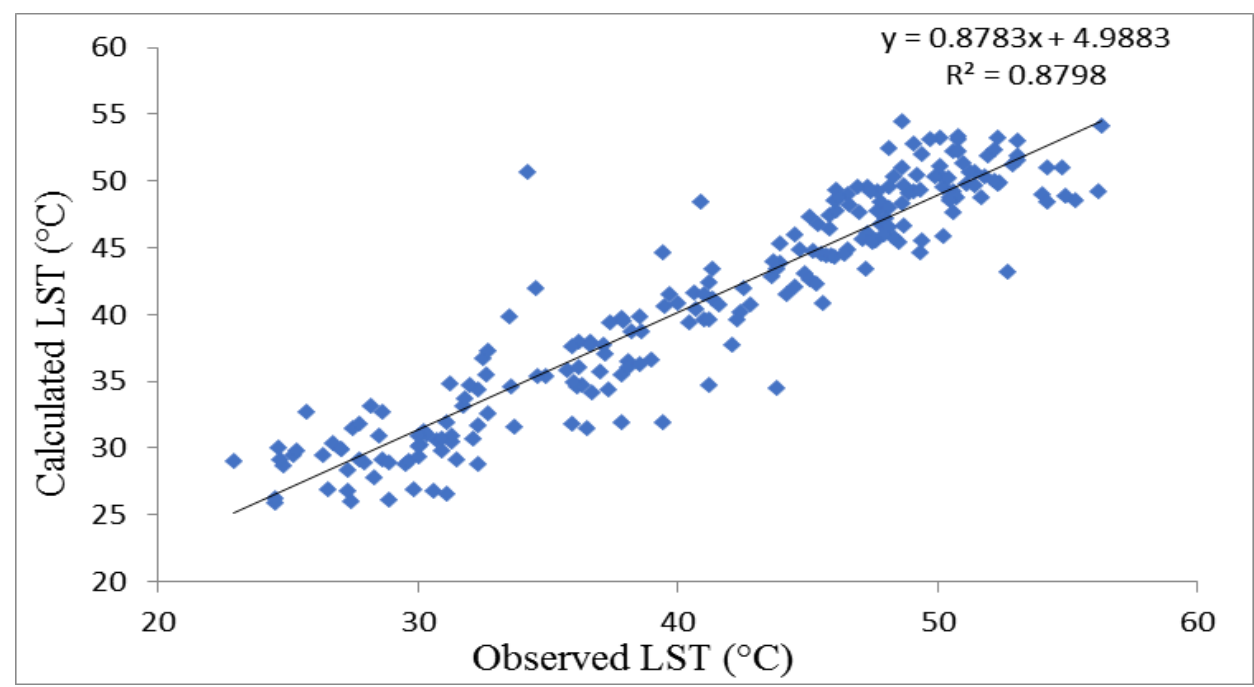

Figure (7): Observed LST during the period (1985 - 2015) at study area.

\section{CONCLUSIONS}

From the data analysis during the studied time range, it could be concluded that the distribution of LST on northern east part is better than the southern part because of the trees that cultivated in the northern part affected on a large area around it and make it decline the temperature. The study emphasizes that it is change for the better must cultivate a new reclamation area to be expansion of the old cultivated area to gain benefit of the land surface temperature reduction. LST is a good indicator to monitoring the climate change

\section{REFERENCES}

Alhawitti, R. and D. Mitsova (2016). Using Landsat-8 data to explore the correlation between urban heart island and urban land uses. IJRET: International Journal of Research in Engineering and Technology, 5(3): 457-466.

Bian, T., G. Ren and Y. Yue (2017). Effect of Urbanization on LandSurface Temperature at an Urban Climate Station in North China. Boundary-Layer Meteorology, 165(3): 553-567.

Duan, S.-B., Z.L. Li, N. Wang, H. Wu and B.-H. Tang (2012). Evaluation of six land-surface diurnal temperature cycle models using clear-sky in situ and satellite data. Remote Sensing of Environment, 124: 1525. 
El-Shirbeny, M. A. and B. Abdellatif (2017). Reference Evapotranspiration Borders Maps of Egypt Based on Kriging Spatial Statistics Method. International Journal of Geomate, 13: 18.

El-Shirbeny, M. A., A.-E. M. Ali and N. H. Saleh (2014). Crop water requirements in Egypt using remote sensing techniques. Journal of Agricultural Chemistry and Environment, 3(02): 57.

FAO (2013). Climate - smart agriculture sourcebook. Available at: www.fao.org/climatechange/climatesmart (last accessed: 15/01/2013).

Goetz, S., R. Halthore, 1 F. Hal and B. Markham (1995). Surface temperature retrieval in a temperate grassland with multiresolution sensors. Journal of Geophysical Research: Atmospheres, 100(D12): 25397-25410.

Guillevic, P. C., J. L. Privette, B. Coudert, M. A. Palecki, J. Demarty, C. Ottlé and J. A. Augustine (2012). Land Surface Temperature product validation using NOAA's surface climate observation networks-Scaling methodology for the Visible Infrared Imager Radiometer Suite (VIIRS). Remote Sensing of Environment, 124: 282-298.

Hasanlou, M. and N. Mostofi (2015). Investigating urban heat island estimation and relation between various land cover indices in tehran city using landsat 8 imagery.In: (eds). Proceeding.

Kuşak, L., and U. F Küçükali (2018). Outlier Detection of Land surface Temperature Kucukcekmece Region. International Journal of Engineering and Geosciences, 4(1), 1-7.

Li, Z.-L., B. H. Tang, H. Wu, H. Ren, G. Yan, Z. Wan, I. F. Trigo and J. A. Sobrino (2013). Satellite-derived land surface temperature: Current status and perspectives. Remote Sensing of Environment, 131: 14-37.

Norman, J. M., M. Divakarla and N. S. Goel (1995). Algorithms for extracting information from remote thermal-IR observations of the earth's surface. Remote Sensing of Environment, 51(1): 157-168.

Ozelkan, E., S. Bagis, E. C. Ozelkan, B. B. Ustundag and C. Ormeci (2014). Land surface temperature retrieval for climate analysis and 
association with climate data. European Journal of Remote Sensing, 47(1): 655-669.

Peltonen-Sainio, P., A. Kangas, Y. Salo and L. Jauhiainen (2007). Grain number dominates grain weight in temperate cereal yield determination: Evidence based on 30 years of multi-location trials. Field Crops Research, 100(2-3): 179-188.

Ranagalage, M., R. C. Estoque and Y. Murayama (2017). An urban heat island study of the Colombo metropolitan area, Sri Lanka, based on Landsat data (1997-2017). ISPRS International Journal of GeoInformation, 6(7): 189.

Stroppiana, D., M. Antoninetti and P. A. Brivio (2014). Seasonality of MODIS LST over Southern Italy and correlation with land cover, topography and solar radiation. European Journal of Remote Sensing, 47(1): 133-152.

Valor, E. and V. Caselles (1996). Mapping land surface emissivity from NDVI: Application to European, African, and South American areas. Remote Sensing of Environment, 57(3): 167-184.

Zahid, M., and G. Rasul (2011): Thermal classification of Pakistan. Atmos. Climate Sci., 1, 206-213.

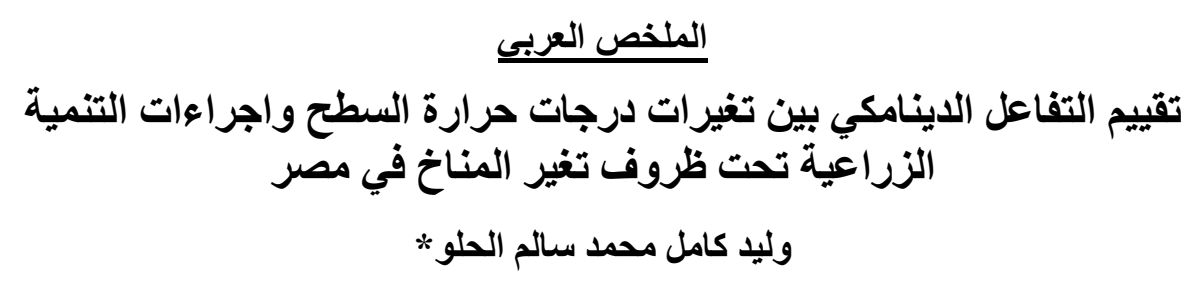

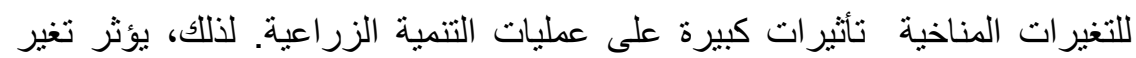

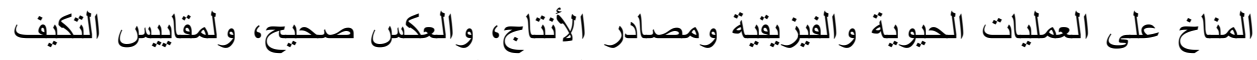

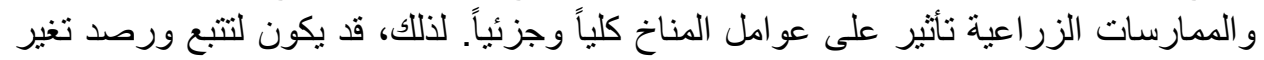

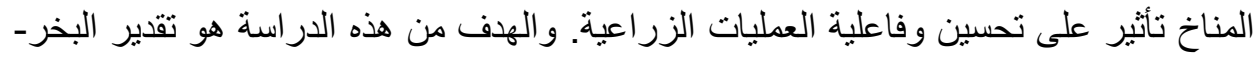

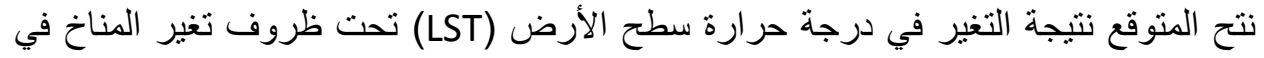

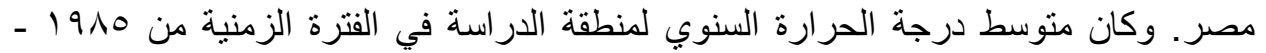

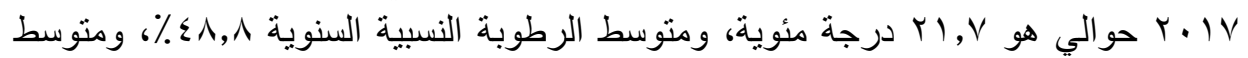

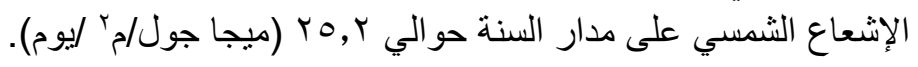

* مدرس الهنسة الزراعية، زراعة عين شمس، القاهرة - مصر. 
وتم أخذ بيانات درجة حرارة سطح الأرض من صور الأقمار الصناعية لاندسات (البعثات 0،

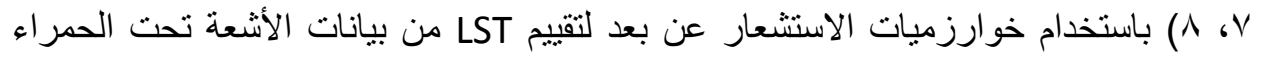

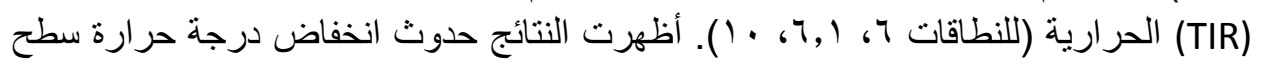

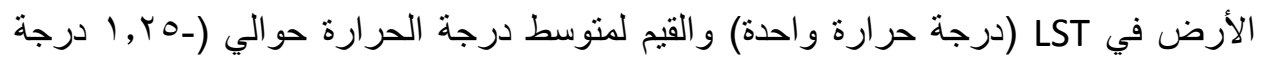
مئوية) خلال فترة الدراسة. التحليل الأحصائي اوضح أنح أن البيانات تأخذ شكل دالة الة خط مستقيم معادلتها:

$$
\begin{aligned}
\text { LST } & =21.185-(11.323 * \text { NDVI })+(0.459 \text { Tmean })+(0.7 * \text { SR })- \\
& (0.078 * \text { RH })-(0.587 * \text { WS })+((0.364 * \text { TDEW })
\end{aligned}
$$

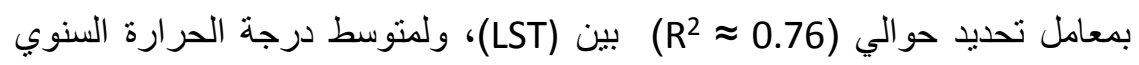

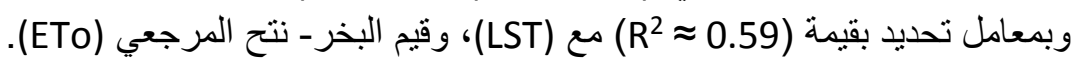

